\title{
China's Confucius Institutes And the "Necessary White Body"
}

\author{
Heather Schmidt
}

Abstract. Confucius Institutes (CIs), modelled on similar European organizations, promote China's official national language and culture abroad. Unlike their European counterparts, however, the interactions between CIs and Canadian audiences are haunted by complex histories of a racialized "Oriental Other" in Canada and "Western Other" in China. Through ethnographic research on the Confucius Institute in Edmonton and the CI Headquarters in Beijing, this paper explores racialized representations of China and Chinese culture, as well as racialized understandings of the desired Western audience, in both locations. I argue that representations of Chinese culture are caught between two competing logics which I term reorientalism and reorientality. Reorientalism attempts to reclaim definitions of Chineseness and redress misunderstandings about China while simultaneously making China comprehensible and ultimately marketable through reorientality, or a use of familiar Orientalist tropes. Canadians (most often imagined and represented as white) are encouraged to engage with this reorientality through their own performance and embodiment of Chinese culture (a conceptually distinct process I call re-orientality) as a means of understanding the project of reorientalism. However, the spectacle of Chinese culture through CIs resonates with Canadian multiculturalism in ways that may unintentionally reproduce a social landscape that normalizes whiteness and the consumption of ethnicized Otherness.

Keywords: Confucius Institute; reorientalism; reorientality; re-orientality; global racial project

Résumé. Les Instituts Confucius (ICs), modelés selon des organisations européennes semblables, promeuvent la langue et la culture de la Chine à l'étranger. Cependant, contrairement à leurs homologues européens, les interactions entre les ICs et les audiences canadiennes sont hantées par leur histoire complexe d'un «Autre oriental» (au Canada) et d'un «Autre de l'ouest» (en Chine), établis de façon raciale. Grâce à la recherche ethnographique au sujet de l'Institut Confucius à Edmonton et à son siège social à Pékin, cette dissertation explore, aux deux endroits, les représentations racialisées de la Chine et de la culture chinoise, ainsi que les conceptions racialisées des audiences de l'Ouest. Dans cette dissertation, je prétends que les représentations de la culture chinoise sont coincées entre deux logiques concurrentes que j'appelle réorientalisme et réo- 
rientalité. Réorientalisme tente de récupérer des définitions de sinité et de rectifier des idées malentendus au sujet de la Chine tout en faisant simultanément la Chine compréhensible et finalement commercialisable par réorientalité, ou une utilisation des tropes orientalistes familiers. Les Canadiens (le plus souvent imaginé et représentés en étant de race $<<$ blanche $>>$ ) sont encouragés à s'engager avec cette réorientalité par leur propres performances et l'incarnation de la culture chinoise (un processus conceptuellement distincts que j'appelle ré-orientalité) comme un moyen de comprendre le projet de réorientalisme. Cependant, le spectacle de la culture chinoise à travers les ICs résonne avec le multiculturalisme canadien par des moyens qui pourraient, sans intention, reproduire un paysage social normalisant «la blanchesse» et la consomption ethnicisée de l'Autre. Mots clés: Les Instituts Confucius; réorientalisme; réorientalité; ré-orientalité; Projets raciales mondiaux

\section{INTRODUCTION}

if s China's increasing economic and political influence has captured I the world's attention, an equally important but less recognized parallel process has been the global dissemination of Chinese culture. Though this process is multifaceted and complex, a significant and stateinitiated component has been the establishment of Confucius Institutes (CIs), and more recently smaller scale Confucius Classrooms (CCs), in host educational institutions around the world. Modelled on, yet distinct from, similar national organizations (such as the Goethe Institut, Alliance Française, and Instituto Cervantes), these institutes are mandated "to promote Chinese language and culture in foreign countries" in order to build "a bridge reinforcing friendship and cooperation between China and the rest of the world" (Hanban n.d.). With more than 700 sites globally (combining CIs and CCs), this project has come to exemplify one instance of the "rising China" theory. Entrusted with a mission to advance China's official language and culture outside of China, Confucius Institutes are key institutional sites through which to examine the production and circulation of Chinese culture aimed specifically at foreign consumption. The representations of China, its language and its culture circulated globally through CIs are driven by particular imaginaries of the country's role in world politics and economics and play a vital role in discursively negotiating China's shifting place globally. They also rely on differently racialized understandings of the Self and one's Other. In Canada, Confucius Institutes become a site in which Western notions of a Self and a racialized, Oriental Other intersect with Chinese notions of a Self and a racialized, Western Other. As each discourse understands its 
Self through its Other, and oscillates between fear of and desire for the Other, CIs become a point at which both discourses become mutually reinforcing.

I conceptualize Confucius Institutes as a global project (Tsing 2008) which imagines and makes globality - a phenomenon in which the world is imagined to be "a single place" (Robertson 1992:395) — in particular ways. The concept of global projects moves away from the temptation to envision a singular cultural logic that is reordering the world, and toward an understanding that, at any given time, there are multiple global projects, each with its own cultural and institutional specificities, and each with its own imaginary of what constitutes that single, global world. CIs, then, are just one global project among many, some working together and some in friction. Confucius Institutes are also a "racial project," being "simultaneously an interpretation, representation, or explanation of racial dynamics, and an effort to reorganize and redistribute resources along particular racial lines" (Omi and Winant 1994:56, original italicized). In the case of China and the ideological work of CIs, it is resources of symbolic capital and not economic capital which the project attempts to reorganize and redistribute. What is at stake is "the power to make people see and believe, to get them to know and recognize, $\ldots$ the power of imposing a [singular] vision of the social world" (Bourdieu 1991:221). As China's economic capital grows, there is a desire to have its symbolic capital increase in step. Indeed, the push by the Chinese state to cultivate China's "soft power" (a concept I will elaborate below) has been continually reiterated over the past several years by the country's leading political figures. What is often overlooked in this push for soft power, and in discussions of its repercussions, is the degree to which race plays an integral role as "a dense transfer point of power" (Stoler 1997:192) through which China can negotiate processes of reorganization and redistribution of symbolic capital globally. While concepts of race combine both fixity and fluidity (Stoler 1997), it has historically been the power of whiteness that has fixed racialized Others in fluid ways. Said (1978:7) calls this "flexible positional superiority, which puts the Westerner in a whole series of possible relationships with the Orient without ever losing him the relative upper hand." The CI project works to move China out of a position of being fixed, of being defined and understood on someone else's terms, and into a position where it has the power to play with fixity and fluidity — that is, into a position where it has "flexible positional superiority" and thus the power to have others accept its own self-made definitions.

As they have expanded globally, Confucius Institutes have been met with a degree of concern that is perhaps unwarranted (Siow 2011; Hartig 
2012). Since funding for CIs is derived primarily from the Chinese government through Hanban (a government affiliated office that administers and oversees CIs globally), there is apprehension that at best CIs are a propaganda arm of the Chinese state and at worst are sites through which it conducts espionage (see for example de Pierrebourg and Juneau-Katsuya 2009, who refer to CIs as a "Trojan horse"). There is also concern in the academic community that such partnerships potentially give the Chinese government (via Hanban and CIs) the power to exert undemocratic influence on Western institutions. Indeed, one of the most common points of contention surrounding CIs is that they, unlike the institutes they cite as models, partner with and are housed within local educational institutions, most typically universities. The recently announced closure of McMaster University's CI (Bradshaw and Freeze 2013) would seem to confirm such a fear amidst allegations of discriminatory hiring practices by Hanban, which stipulates members of CI staff cannot be practitioners of Falun Gong, a spiritual movement banned by the Chinese Communist Party. As CI teachers sent from China are hired by Hanban, institutions such as McMaster are seen as supporting such discriminatory practices by proxy.

The existence of apprehensions over Confucius Institutes rests on a politicized othering of China in which the communist Other is imagined as a foil to the democratic Self. In keeping with this preoccupation with China as a politicized Other, most academic commentaries on CIs have tended to focus on their soft power aspects (Yang Rui 2010; Paradise 2009; Ding Sheng and Saunders 2006; Gil 2008). A term coined by Joseph Nye (1990), soft power "co-opts people rather than coerces [and] rests on the ability to shape the preferences of others" (Nye 2008:95). While it would be unwise to lose a critical lens when regarding any stateinitiated project, the literature on soft power and CIs is seldom based on any empirical evidence of what CIs actually do (Hartig 2012), nor what influence they actually garner. As noted above, the notion of soft power has gained a lot of cachet in China among political leaders (Li 2009), making it an important area for research. Yet English-language scholarship has tended to involve broad generalizations myopically focused on the negative implications of China's soft power, an assumption which follows a logic that all things democratic are good (as seen in the more positive portrayals of US soft power) and all things nondemocratic are bad. Such concern over communist influence, or the "red peril," is entwined with racialized historical fears of a "yellow peril" (Breslin 2010), a 19th century fear of yellow bodies that embodied multiple anxieties including increased East Asian immigration, military aggression, economic competition, and social degeneration (Keevak 2011:126, citing Thompson 
1957). Today, there have been changes in the way we talk about such fears, but the underlying tensions remain unchanged. Anxieties still lie behind debates over immigration, and we can still readily find fears over China's possible military aggression, economic competition, and social degeneration (articulated now as communist threat to liberal democracy rather than pagan threat to Christendom). In this complex mix of politicized and racialized fears of China, the articulated threat of the red peril displaces the now-unarticulated threat of the yellow peril. That is, the politicized Othering of China masks racial undertones and the continued haunting of racial thinking in global forums.

Perhaps the most feared implication of all is that a "rising China" must inevitably mean a "declining West." This fear of "a loss of centrality" has instigated an "identity crisis" in the West (Barr 2011:6), which I argue CIs both feed and mitigate. Economically, the growing disparity between Western economies increasingly plagued by debts and failing markets and China's growing financial clout is especially highlighted in CIs as China steps in to offer substantial amounts of money and resources (e.g., teachers, performers, books, digital equipment, software, etc.) to educational institutions increasingly starved of funding. The discomfort with the growing financial power of China that this brings to the fore, and the loss of Western centrality at which it hints, is what is truly fearful. Culturally and racially, however, CIs present an orientalized, exoticized, and ancient China, which marks itself as different against a normalized white, Western other, enabling Westerners to continue feeling central and thereby unthreatened.

In Canada, the CI project takes on particular forms that resonate with popularized notions of the country's multiculturalism and ideas about global citizenship. Building on Huggan's (2001) theories of "the postcolonial exotic," I see the Confucius Institute project in Canada as operating between two regimes of value which I term reorientality (a purposeful recycling of orientalist tropes of China) and reorientalism (an attempt to redefine China on its own terms). By making Chinese culture a spectacle of Otherness through reorientality, CIs fit comfortably in a landscape which has normalized the consumption of ethnicized Otherness. In the process, they also reinforce the normalization of whiteness by centring it as the unmarked category against which Chineseness is made "different." By moving beyond mere spectacle and actively engaging their audience, CIs entice Canadians to not only consume but embody particular versions of Chinese culture through a process that I call re-orientality (which I will define later as conceptually different from reorientality), so as to ultimately feel Chinese culture and thereby become invested in China. Importantly, these versions of Chinese culture with which Can- 
adians are asked to engage are defined by China itself through reorientalism and thus carry the potential to destabilize Western-centric orientalist visions of China.

This article draws from my ethnographic research on the Confucius Institute in Edmonton (CIE). While the arguments I lay out in this article may be more broadly applied to other CIs in Canada, it still must be noted that each $\mathrm{CI}$ is unique. It is also important to acknowledge that the racial dynamics through which CIs operate will be different in locations where the main populace is not white. However, as a project that marks culture (and by extension ethnicity and race) CIs rely on and reproduce racializations in all places, and I would encourage other researchers to examine the underlying racial thinking behind the $\mathrm{CI}$ project in different locations. My research on CIE focused on the institutional networks within which it is situated, including its two founding partners, the Edmonton Public School Board (EPSB) and the Shandong Provincial Education Department, as well as the Confucius Institute Headquarters in Beijing (Hanban) and the Edmonton Chinese Bilingual Education Association (ECBEA). CIE was established in 2008 and I have conducted ongoing research since 2009 , including twelve semistructured interviews with key personnel in Edmonton, ${ }^{1}$ Shandong, and Beijing, probing similar issues in each location such as: institutional network structure; daily operations; goals and challenges; representations of China (including why these representations in particular and why they are deemed necessary); the significance of CIs to China and Canada; their present significance; and reactions to CIs in Canada. My participant observation in all three locations paid particular attention to how China and Chinese culture are represented and for whom. In Edmonton, I observed CIE's classes, public events, demonstrations in schools, and administrative meetings and attended monthly ECBEA meetings where CIE gives updates on its involvement with Edmonton's public schools. In China, I accompanied a group from Edmonton, led by CIE in the summer of 2011, to Liaocheng University in Shandong for a two-week immersion program, and attended in 2011 and 2012 the annual Confucius Institute conference in Beijing hosted by Hanban. These annual conferences have been a particularly rich site for research as they bring together $\mathrm{CI}$ directors, assistant directors, teachers, and organization heads from partner institutions across China and around the world. On display at these conferences, especially during the opening ceremonies, is a centralized version of the Chinese culture Hanban hopes CIs exemplify abroad.

1. In 2010, I also interviewed, via telephone, two CI Directors in other locations in Canada. Though I have since limited my research to Edmonton specifically, these interviews have provided further support for my findings at CIE. 


\section{China's Racialized "Preferred Other"}

The Chinese government itself is not unaware of Western fears of China, and the CI project can be understood on one level as an image management campaign. Indeed, Hanban often refers to Confucius Institutes as a "brand" and brands are all about making particular associations in relation to a product - in this case, China. Many countries are involved in programs that similarly extol their national virtues abroad, none more so than the United States (see, for example, Rosenberg 1982). Not all countries, however, are in the same financial position to carry it out in the manner and to the extent that China does. So if CIs are seen as one arm of a broader branding campaign, then we must also ask what image is being presented (which I will consider in the next section) and for whom? Just as China operates as an important Other to the West (Vukovich 2012), so too does the West operate as China's "preferred Other" (Chow 1997:151; see also Chen 1995; Dai 2001). A crucial function of Confucius Institutes is to demonstrate to the world the richness of Chinese thought and the value of Chinese culture. ${ }^{2}$ In the words of Madam Xu Lin, DirectorGeneral of Hanban: "In some way the world will realize, sooner or later, that Chinese culture is the best one in the world" (Guangming Net 2010, italics added). If we accept Dai's (2001) argument that in China there is a conflation of the West (and America) with the world, then we might begin to understand what (or who) specifically is imagined when "the world" is referred to as an agentive subject. Indeed, if one were to take the placement of CIs as an important indicator of Hanban's target audience, then the fact that the United States hosts the largest number of CIs of any country (nearly one quarter of the global total) is significant. If we consider the total number of CIs in what may be considered "Western" locations (i.e., North America, Europe, and Oceania) then well over half can be found in "the West." 3

While "the West" is, in fact, not a geographical concept but a historical one (Hall 1992), it is still widely used when referring to societies imagined to be "developed, industrialized, urbanized, capitalist, secular, and modern" (1992:277). To this list, I would add "white," as race plays a critical role in imaginaries of the West - both in how it is perceived by Western Selves and non-Western Others. The preferred Other of CI pro-

2. In writing this, I have in mind a quote from Fanon (1967:10): "There is a fact: White men consider themselves superior to black men. There is another fact: Black men want to prove to white men, at all costs, the richness of their thought, the equal value of their intellect."

3. That there is an uneven and geographically strategic distribution of CIs across the globe can also be seen by the fact that only about 20 of the over 300 CIs are located in all of Africa, despite China's interest in the continent. After "the West," Asia hosts the second largest number of CIs, the majority of which are located in Korea, Japan, and Thailand. 
grams is not only a Western (American) Other, but specifically a white, Western (American) Other. Whereas earlier Chinese state programs of outreach abroad have focused on overseas Chinese communities (Barabantseva 2005; Nyíri 2001; Thunø 2001), CIs aim to expand beyond diasporic communities and indeed target a "mainstream public that mostly does not have any special China-knowledge" (Hartig 2012:63). In Western locations, such as Canada, this "mainstream" audience is imagined as white. The conflation of whiteness with Westernness in China (Schein 1994; Stanley 2013; Ilnyckyj 2010) is not unlike the conflation of whiteness with Canadianness that happens in Canada itself (Bannerji 2000; Mackey 1999; Paragg 2012). In a Canadian Confucius Institute such as CIE, then, these two imaginaries from China and Canada of the Canadian body as white meet up and mutually reinforce one another. While CIs are solicited by Hanban to submit articles about their events and activities for publication in its Confucius Institute magazine, a CI director recounted a story in which Hanban rejected the submission because the students shown in the attached pictures were Asian - or more to the point, not what a "Canadian" is presumed to look like. The director explained the rejection (with both humour and cynicism) by noting: how can Hanban justify its program of outreach to "foreigners" - and the huge sums of money it requests from the central government to spend on CIs - if the foreigners don't look foreign? A brief survey of the front covers of the English version of the Confucius Institute magazine also shows the centrality of white bodies to the CI project. Of the 18 issues I have collected since the first volume in March, 2009 (from a total of 23 between 2009-2012 ${ }^{4}$ ), fifteen covers display white, Western bodies usually as the focal point, but not always - typically engaged in some aspect of Chinese culture, be it calligraphy, martial arts, Beijing opera, or tea ceremonies. The Westernness of these white bodies is grounded by captions that refer to either their location or point of origin in the UK, US, Australia, or Europe. The non-Chinese body, and specifically the white body, becomes necessary to the CI project as an exemplar of its whole mission. However, it is important to keep in mind that, contrary to Chow (1997) and Dai (2001), racially informed standpoint epistemologies cannot be seen as "mere reactions to or simple negations of 'Western' cultural/theoretical epistemologies" (Omi and Winant 1993:8). Rather, we should consider what significance the Western Other has as that against which the Chinese Self is imagined.

4. The Confucius Institute journal is released bimonthly, with a total of 6 issues each year. In the first year of 2009 , however, there were only 5 issues published, for a total of 23 over the 4 year period. 
In his overview of how the West has been conceptualized by China's intellectuals since 1949, Wang (2003) demonstrates two discourses of the Other/other. Using Lacan's distinction between an uppercase Other (which stands in direct opposition to the Self) and a lowercase other (which represents something the Self desires to become), Wang demonstrates that, whereas prior to the Cultural Revolution China's historians sought "a demonized Other" (2003:342) "to show the 'superiority' of Marxism" (2003:335), after the Cultural Revolution, disillusionment with the recent past caused young historians to turn to the West in search of an other that exemplified the economic development and modernization they desired for China. This use of a dichotomized Western O/other in Chinese intellectual discourse - which is also demonstrated by Chen (1995) in her discussion of official and antiofficial Occidentalisms shows that, just as in the West, any imaginary about the Other is in fact less about that Other than it is about the Self. While Wang's overview ends in 1989, given the disenchantment with the West and in particular America since the 1990s, portrayals of Westerners have become all that more complex, representing simultaneously both the demonized Other and desired other. Conceison (2004) gives us a sense of the interplay between the split halves of the essentialized American O/other through an examination of contemporary Occidentalist representations of Americans in live theatre performances in China, which rely on a synthesis of positive and negative essentializations of the foreigner.

Racializations of the self and other in China are as deeply rooted in history as those in the West, and are indeed built out of the same discourses. At the end of the Qing dynasty, many Chinese intellectuals accepted the scientific reasoning of Western racial categories, including the term "yellow" as a label of self-identification. As the colour has a long history of symbolic significance and positive association in China (Bonnett 1998; Keevak 2011; Dikötter 1997), being designated yellow was a "happy coincidence" (Keevak 2011:7) and easily inverted to become a positive connotation of self-identification rather than a racial slur. However, the Chinese adoption of "yellow" as a racial marker was not and is not simply an absorption and replication of Western racial categories (Bonnett 1998). While at the turn of the 20th century, the Western science of race was accepted by many in China, the same was not true of the hierarchical organization of races which seated white above all others. During the late Qing era, the matching superiority of the yellow race was demonstrated through a dual process of disidentification and identification with whites: while Chinese were certainly "not-white" (being morally and culturally superior), they were also constructed to be "like-white" vis-à-vis the "darker races" (Teng 2006:152). This intel- 
lectual work to make room within Social Darwinism for two superior races demonstrates the malleability of racial discourse. Like many ideas imported from the West, racial thinking was accepted in China but importantly readjusted and localized (Bonnett 1998; Keevak 2011; Teng 2006; Dikötter 1997). Such discourses not only continue into presentday China, but remain relatively uncontested, as are the hierarchies of power built upon them (Dikötter 1997).

\section{China Re-Orientalized}

One of the most intriguing things about Confucius Institutes is that, while their mandate is to cultivate an understanding of China as it is today, it does so by conveying traditional aspects of Chinese culture which highlight its antiquity. During my interviews, both Canadian and Chinese administrators have expressed the grievance that Westerners have little understanding of contemporary China. They note that even though China has changed drastically in the thirty plus years of economic reforms, Western imaginations are still mired in a vision of China as closed, undeveloped, authoritarian, and ultimately "backward." One major impetus for the CI project, then, is to show "the world" (which we have seen is conflated with "the West") that China is not antiquated as is thought, but that there has been fast-paced and sweeping development. When asked why China is investing so much into CIs and why now in particular, a Canadian CI director commented that China has realized that the world is not viewing "the new China" - that the world still holds a perception of China as a "third world country." China therefore, he continued, wants to change perceptions of who it is, what it is doing, and what freedoms it has, to counter Western media portrayals of an oppressive China. The entrenchment of China as Communist Other in the Canadian imaginary, the racialized undertones of that imaginary, as well as the failure of Canadians to comprehend contemporary China, can be found in the words of another Canadian CI director who explained CIs offer Canadians an opportunity to come to a "true understanding" of Chinese people, instead of "you know, the political, racial, communist thinking sort of thing." The hope is to demonstrate through CIs that China is transformed: it is not what it once was.

There is also an awareness in China that it is these very rapid and expansive transformations that provoke fear (Breslin 2010). Since CIs, and China's "charm offensive" (Kurlantzick 2007) more broadly, are meant to mitigate growing fears about China's rise, they work to soften China's image, attempting to make it more enticing than fearful. But if being modern, developed, and an economic powerhouse are those very aspects 
of China that are fearful, what ground is left for representation? Furthermore, as cultural and racial identity is "a positioning" (Hall 1990:226) rather than an essence, representations of Chineseness by CIs attempt to position China in relation to its preferred Other - the racialized, white, Western O/other. Chineseness is that which is "not the West." If the West is understood to be developed, industrialized, urbanized, and modern (Hall 1992), how then can China represent its development, urbanization, industrialization, and, most importantly, its modernity if it is meant to be "not the West"? In the title of his book, Barr (2011) asks the question: Who's Afraid of China? The answer, he writes, is dependent on the issue under consideration: any individual, community, or country "stands to win and lose at the same time, depending on what criterion is used" (2011:2, italics added). This notion of winning and losing hinges on a dualism of good/bad, the desired and the feared often attributed to racialized Others. Similar to tropes that have split Aboriginal populations into dichotomized figures of noble/savage, so too is China often essentialized and then split into exotic/peril. We might reconsider Barr's question, by asking more specifically: What is frightening (or perilous) and what is enticing (or exotic) about China? Perhaps in an effort to de-emphasize its modernity (and thus its economic power and political otherness which have become points of contention), Confucius Institutes, in Canada at least, tend to orientalize China. Representations of China highlight the traditional and ancient: women clad in qipaos (traditional form-fitting dresses) playing pipas (a stringed instrument similar to a lute) and guzhengs (similar to a zither); women dressed in imperial garments and headdress performing elaborate tea ceremonies; men wearing changshan-style costumes (traditional male garments worn like a robe the length of the body) or Tang-style jackets (made from colourful brocades) at display booths promoting Confucius Institutes; men in silk martial arts uniforms performing tai chi. Such Orientalist representations in CIs play on and play into long-held Orientalist ideas in the West about what China is: intriguing, mysterious, exotic, enticing, and most definitely "Other."

In highlighting those things which are appealing to Westerners, CI representations of China can be seen as not only a discursive strategy to shift attention away from those aspects of modernity and development that make China fearful and threatening, but also as a move that sidesteps China's more recent history since 1949. Thus, in the desire to move away from sensationalized images of China as antiquated political Other - stuck in a recent past of autocratic rule and subsequent underdevelopment - the CI project ends up portraying China as anachronistic cultural/racial Other. If China is represented as occupying 
"anachronistic space, a land perpetually out of time in modernity" (McClintock 1995:41), then it ceases to be threatening, but it does so precisely because it cannot occupy the same space of modernity as the West. There is a conundrum of wanting "the world" to understand China as it is today, while relying on representations of China as it was in the past to mitigate the very fears aroused by China as it is today. For those at work in the CI project this is not as contradictory as it may at first seem. When questioned on this seeming incongruity, a CI teacher from China explained:

... The main value is not just to know the traditional art. It's about the ideas that, you know, are carried by this art. Like for example, when we are doing paper-cutting, all the patterns are about happiness, about peace, about harmony. And when people enjoy this art they also have, you know ... they form a view of harmony, and of peace.... And Hanban asks us to introduce those traditional arts to the foreign countries. Not just to teach them art lessons. If we just teach art lessons that's, you know, about education but not bridging, you know, not about a cultural bridge ... when we are teaching those traditional arts we are trying to let people feel our, you know, warmth inside, and feel our, you know, like, life values. (emphasis added)

The hope then is that activities, events, and classes which spotlight the traditional and ancient will impart a sense of the social values that continue in China today. Chinese traditional culture can be tapped as a means of understanding some Chinese essence that continues into modern times. As Xu Jialu, an intellectual and political figure in China who has figured prominently in the CI project, put it in his speech at the opening ceremony of CIE, spreading Chinese language and culture (the mandate of CIs) also spreads the philosophies behind that language and culture (personal interview, 24 June 2009). Here, I am drawing attention to how the process is understood by those who work and are invested in the CI project. It is necessary to keep in mind that how it is narrated is not necessarily what is happening.

Perhaps it would be best to consider this adoption of Orientalism, or this re-Orientalism (Lau 2009:572), "a process of Orientalism by Orientals," as similar to earlier adoptions of Western scientific racial discourse, which were accepted but readjusted to suit China's own ends. In this way, we can acknowledge that an appropriation of Orientalism does not necessarily mean abjection, whereby the (semi-)colonized internalizes the colonizer's discourse to the point where the Self becomes the abject object (Fanon 1967). The purposeful owning and production of otherness through CIs is an intentional (and official) proliferation of difference which makes use of stereotypes of China. Rather than an internal- 
ization of externally given labels of difference, use of the Oriental in CIs seems to almost invert abjection by wilfully drawing on such expected stereotypes. This is something other than simply a postmodern sense of semiotic playfulness. Appropriating Orientalism becomes a means of harnessing the "flexible positional superiority" upon which it depends and thereby gaining "the relative upper hand" (Said 1978:7). If representations of China do indeed take some form of Western modernity as an unmarked category against which Chineseness is Other, then they also do so with the understanding that that unmarked Western modernity signifies Enlightenment ideals which have led to the failings of liberal democratic systems in global governance. China hopes to step in and offer different and alternative systems of thought. An understanding of China's difference rests not only on a sense of its history and traditions, but also on the premise that Chinese culture offers something unique and significant to the world which can help address contemporary global problems. In the words of Madam Xu Lin:

People have found that in the past 30 years the West has made a bad mistake, and that China has been learning valuable experiences from the West whilst the West has learned nothing from China ... western economic theory and cultural values are inadequate for solving current problems. Even Westerners think so. The West needs to seek answers from the East.... People admire China and consider Chinese culture and values to be superi$o r$, in some respects, to those of the West ... people of other countries have accepted our culture: Confucianism. (Guangming Net 2010, italics added)

The move to re-orientalize Chinese culture, therefore, may not indicate the global racial formation (Omi and Winant 1994) one might expect. It is not so much about the extraction of cultural raw materials from exotic locations for consumption in Western metropoles (Kearney 1995) as it is about an intentional exportation from China to locations around the globe. In this purposeful exportation from China, there are competing agendas. The desire to show China as it is today - to dispel misunderstandings and stereotypes of China as political other - gets bound up with the realization that orientalism, as a branding tool, sells. These representations of Chineseness through CIs function much like Huggan's (2001) "postcolonial exotic," occupying a site of discursive conflict between two regimes of value - one that is oppositional and works to destabilize Western representations of the Other (postcolonialism), and one that capitalizes on the marketability of Otherness in the global economy (postcoloniality). Re-Orientalism can similarly work both "deconstructively from within hegemonic discourse" (Salgado 2011:202), attempting to wrestle back control over definitions and rep- 
resentations of China, as well as "constitutively within hegemonic discourse" (2011:204), ${ }^{5}$ normalizing whiteness as that which Chineseness is marked (and marketed) against. In this way, CIs may indeed create a particular positive awareness and openness toward China, as is hoped, but they do this by marking China as "Oriental Other" to a racially white West. This re-orientalized representation of Chineseness mitigates fears and holds the West's identity crisis (Barr 2011) at bay precisely because it enables Westerners to continue feeling central. The traditional and ancient Chinese body, unlike the modern Chinese body, is not threatening, and what is more, it is enriching of "us." The Chinese culture circulated through CIs works to fill the "emptiness" of whiteness and compensate for its lack of culture (Frankenberg 1993).

Building from Huggan's (2001) work, I propose the terms reorientalism/reorientality (in place of postcolonialism/postcoloniality) as the two competing regimes of value at work in the CI global project. While Hanban attempts to reclaim definitions of Chineseness and redress misunderstandings about China (reorientalism), it is also caught in the commodity logic of global capitalism and the historical dominance of the West which has made China comprehensible through orientalist tropes (reorientality). As I will outline in the next section, what I term re-orientality (distinct from reorientality) also has significance to my argument as that which indicates an attribute of affect that CIs invite participants to embody momentarily though particular Chinese cultural activities.

\section{The Necessary White Body}

There is perhaps a growing awareness among China's leaders that a nation's image abroad "exists in many people purely as affect with no knowledge basis whatsoever" (Kunczik 1997:43, italics added). As I have mentioned above, in looking at racialized fears of China, this is the case. Concerns over Confucius Institutes are driven more by expectation than actual experience. Indeed, "it is the attitude that seeks the content rather than the content that creates the attitude" (Fanon 1967:158, quoting Joachim Marcus in a footnote). The goal for China, then, is to shift those attitudes from negative to positive - to turn the fear of China into affection toward it. It is to this end that Confucius Institutes put culture into service. My goal here is not to define culture so much as interrogate how culture functions as a resource for attaining an end (Yúdice 2003),

5. Salgado differentiates these two possibilities by referring to the former as reOrientalism and the latter as re-Orientalism, but I have chosen rather to employ and build on Huggan's terminology further on in the paper. 
and in particular "the kinds of racializing work that ideas about culture perform" (Visweswaran 2010:3).

What CIs accomplish is not so much a labelling of Chinese people as racially different per se, but rather of particular cultural activities as Chinese. It is through their participation in Chinese cultural activities that non-Chinese people, it is hoped, can begin to feel Chinese culture. This sentiment has come up time and again in my discussions with CI administrators and teachers, both in Canada and in China. Confucius Institute activities and events are not simply about displaying Chinese culture to a non-Chinese audience (though CIs do hold traditional performances). Rather, they are typically structured in ways that actively engage the audience, soliciting its participation. Activities are frequently composed of two parts, a demonstration of the activity by a teacher or expert, followed by a hands-on component in which the audience is asked to themselves do the cultural activity (be it calligraphy, knot tying, paper cutting, Beijing Opera, etc.). By participating in Chinese culture, however momentarily, CIs hope audience members will develop an affection towards Chinese culture and thereby China itself. The key to these activities is not just to inform non-Chinese about Chinese culture, but to get them to experience it on an emotional level. CIs, then, employ a "politics of affect" (Eng 2006:52), in which affect, emotions, and passions are mobilized to particular ends, creating "affective economies" (2006:53) that are inextricably bound together with political economies. ${ }^{6}$ The ultimate pinnacle of the CI project is the production of non-Chinese (preferably white) bodies with a level of mastery in Chinese language and culture sufficient for on-stage or TV performances that become a spectacle for audiences in China (see image).

Since the 1990s, an increasing array of foreigners have appeared on China's theatrical stages (see, for example, Conceison 2004), in TV series (see, for example, DeWoskin 2005), and reality shows (see, for example, Morrow 2013). At times, these foreigners serve as a foil to Chineseness, displaying a negative Otherness against which Chinese superiority can be measured. They can also serve as a mirror, demonstrating a desire for things Chinese through mimetic cultural performance. The foreigner who dons traditional costumes and performs Chinese culture for audiences in China (as in the cover photo on the next page) serves to "stoke Chinese national pride" (Lee 2006:526), and in this way "the figure of the foreigner is crucial to the national project of self-reinvention"

6. Eng theorizes about a "politics of affect" in the light of much different phenomena than CIs. While the application of this term to CIs does not describe the "ethically reflective psychoanalytic project" (2006:52) Eng hopes for, I still find it useful in describing what is happening through CIs. 


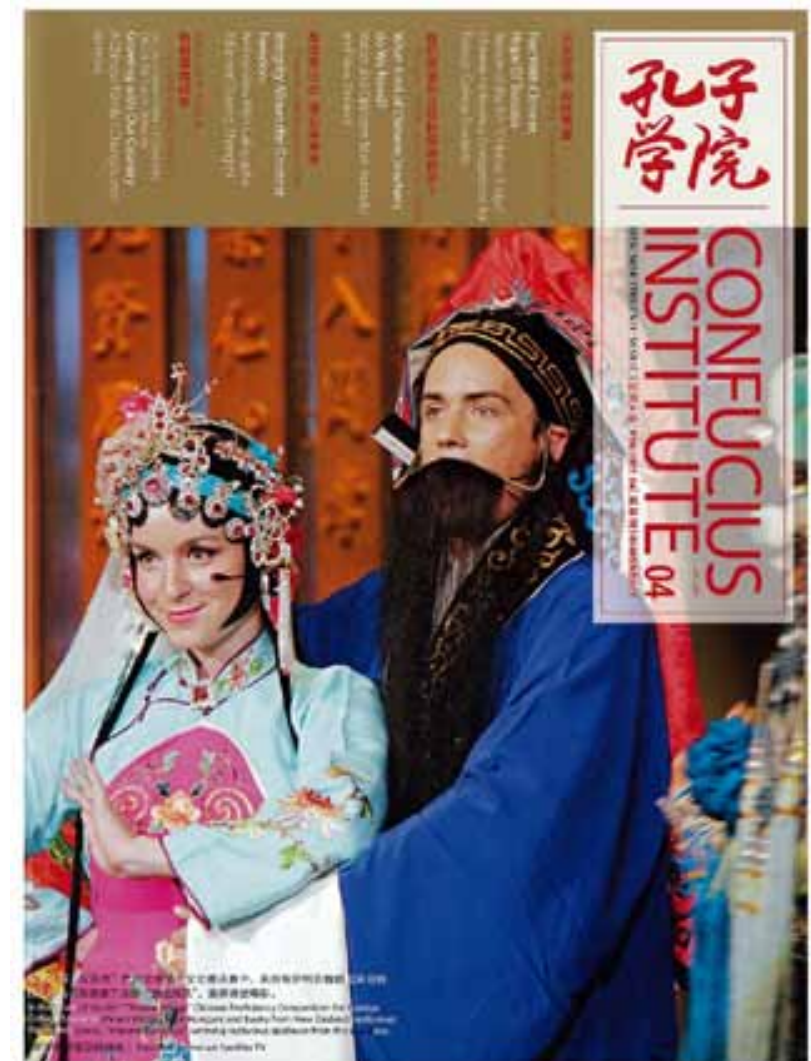

Cover of the September 2009 edition of the English edition of the Confucius Institute magazine published by Hanban.

The image is of a performance from the finals of the 8th Chinese Bridge Competition, broadcast in China by CCTV, a national network

(2006:526, italics added). Yet, it is more complex than simply a means of validating the worth of Chinese culture. Interaction with foreigners (imagined, mediated, or otherwise) becomes a training ground for the rebirth of Chinese people as cosmopolitan subjects in the neoliberal world order (2006:526-7). Lee's reference to the figure of the foreigner as "crucial" is similar to how I theorize the white, Western body as "necessary" to the CI project. It is important to note that this does not always indicate a global racial power dynamic in which white dominates non-white - for the foreign is often made to serve China (Brady 2003) and foreigners are easily "shanghaied" into doing things not of their own choosing which may work toward interests other than their own (Stanley 2013), even without their own cognizance of such dynamics. 
The white body is important not only as the unmarked against which Chineseness is marked, but as a necessary stand-in for any non-Chinese body. If, as I have argued, "the world" is conflated in China with "the West/America," then the white body imagined as representative of "the West/America" can also signify "the world." In the CI project, the white body in particular becomes necessary to a performative display of Chineseness, not as a consumer of that display but as the performer him/ herself. Since white Westerners operate as the preferred Other in China, the white body performing Chinese language and culture becomes the idealized embodiment of China's global outreach program through CIs. These performances are about garnering a positive affect toward China through momentary embodiments of Chineseness. Lancefield (2004), in his examination of early 20th century US representations of the Orient in musical performances, uses the term "orientality" to refer to "what it was' that many people felt they heard or saw or embodied in moments of orientalist performance" (2004:41, italics added). Combining Lancefield's use of orientality with Lau's (2009) term re-Orientalism, I argue that what is happening in the performance of Chinese culture by nonChinese bodies in CI activities is a process I am calling re-orientality (conceptually distinct from reorientality or that marketable, orientalist aspect of Chinese culture I theorized earlier), in which the non-Chinese body (preferably a white body) is asked to momentarily embody and thus feel Chineseness in some way. Whereas in Lancefield's study orientality functions through a process of Orientalism by Occidentals (in the Saidian sense), in Confucius Institute activities the experience functions through "a process of Orientalism by Orientals" (Lau 2009:572). This process of Orientalism by Orientals in CIs hinges on regimes of value which attempt to both rectify misunderstandings of China though reorientalism while making China comprehensible and marketable through familiar Orientalist tropes or reorientality. The (white) non-Chinese body is invited to engage with reorientalism through reorientality by performing and thereby embodying Chinese culture and feeling an emotional engagement, or re-orientality, with particular imaginings of China.

\section{Conclusion}

American views of China vacillate between a demonized threat and a romanticized fantasy of China becoming Americanized (Conceison 2004). For Vukovich, this is also the thrust behind Sinological-orientalism, which turns on "China's becoming sameness" (2012:1). In Canada, however, I argue the romanticization is less about "them" become more like "us," and more precisely because "they" are a different, ethnicized 
Other that enriches our "us." CIs offer an "authentic" version of Chinese culture right here in Canada, or as one Canadian administrator put it: "It is like having a little piece of China [here]." The CI project resonates with Canada's multicultural project and feeds white desire for the racialized Other. In an atmosphere where "[t] $]$ he average Canadian still thinks of multiculturalism as ethnic celebrations of song and dance" (George 2006:61), CI activities and events which promote China's traditional culture play into this notion of "song and dance multiculturalism."

As a global racial project, CIs meet and resonate with other global and racial projects in the West. The normalization of white, Western bodies as representative of "the world" in CI promotional material, and the desire to nurture a "sinofied" subjectivity among non-Chinese people, which I have termed re-orientality, works in tandem with Canadian ideals of multiculturalism and global citizenship to coproduce a particular globalized subjectivity. While CIs contain the possibility of what I call reorientalism, or the ability to disrupt and rewrite orientalist tropes, they also are bound up in the logic of global capital, marketing China and Chineseness as "Other" (which I have referred to as reorientality). Thus, unfortunately, what has the potential to be transgressive is not always transformative (Mitchell 2004). Problematically, CIs not only re-orientalize China but all Chinese bodies, including Chinese Canadians, reinforcing the tendencies of multiculturalism to other nonwhite Canadians (Bannerji 2000) and make the nonwhite body somehow not Canadian enough.

\section{REFERENCES}

Bannerji, Himani. 2000. The Dark Side of the Nation: Essays on Multiculturalism, Nationalism and Gender. Toronto: Canadian Scholars' Press Inc.

Barabantseva, Elena. 2005. Trans-nationalising Chineseness: Overseas Chinese policies of the PRC's central government. Asien: The German Journal on Contemporary Asia 96:7-28.

Barr, Michael. 2011. Who's Afraid of China? The Challenge of Chinese Soft Power. New York: Zed Books.

Bonnett, Alastair. 1998. Who was white? The disappearance of non-European white identities and the formation of European racial whiteness. Ethnic and Racial Studies 21(6):1029-1055.

Bourdieu, Pierre. 1991. Language and Symbolic Power. Cambridge, MA: Harvard University Press.

Bradshaw, James, and Colin Freeze. 2013. McMaster closing Confucius Institute over hiring issues. The Globe and Mail, February 7. 
Brady, Anne-Marie. 2003. Making the Foreign Serve China: Managing Foreigners in the People's Republic. New York: Rowman \& Littlefield Publishers, Inc.

Breslin, Shaun. 2010. China's emerging global role: Dissatisfied responsible great power. Politics 30:52-62.

Chen, Xiaomei. 1995. Occidentalism: A Theory of Counter-discourse in PostMao China. New York: Oxford University Press.

Chow, Rey. 1997. Can one say no to China? New Literary History 28(1):147151.

Conceison, Claire. 2004. Significant Other: Staging the American in China. Honolulu: University of Hawai'i Press.

Dai, Jinhua. 2001. Behind global spectacle and national image making. Positions 9(1):161-186.

de Pierrebourg, Fabrice and Michel Juneau-Katsuya. 2009. Nest of Spies: The Startling Truth about Foreign Agents at Work within Canada's Borders. Translated by R. Conlogue. Toronto: HarperCollins Publishers Ltd.

DeWoskin, Rachel. 2005. Foreign Babes in Beijing: Behind the Scenes of a New China. New York: W.W. Norton.

Dikötter, Frank. 1997. Racial discourse in China: Continuities and permutations. In F. Dikötter, ed., Construction of Racial Identities in China and Japan. Hong Kong: Hong Kong University Press.

Ding Sheng and Robert A. Saunders. 2006. Talking up China: An analysis of China's rising cultural power and global promotion of the Chinese language. East Asia 23(2):3-33.

Eng, David L. 2006. Political economics of passion: Transnational adoption and global woman. Studies in Gender \& Sexuality 7(1):49-59.

Fanon, Frantz. 1967. Black Skin, White Masks. Translated by C.L. Markmann. New York: Grove Press.

Frankenberg, Ruth. 1993. White Women, Race Matters: The Social Construction of Whiteness. Minneapolis: University of Minnesota Press.

George, Usha. 2006. Multiculturalism, issues in Canada. Canadian Diversity/ Diversité Canadienne 5(2):60-61.

Gil, Jeffrey. 2008. The promotion of Chinese language learning and China's soft power. Asian Social Science 4(10):116-122.

Guangming Net. 2010. Xu Lin: Chinese language quickly going global is a great phenomenon - A special interview with Chinese State Council Consultant and Director General of Hanban. Hanban News.

Hall, Stuart. 1990. Cultural identity and diaspora. In J. Rutherford, ed., Identity: Community, Culture, Difference. London: Lawrence \& Wishart. 1992. The West and the rest: Discourse and power. In S. Hall and B. Gieben, eds., Formations of Modernity. Cambridge: Polity Press. 
Hanban. n.d. About Confucius Institute/Classroom. Cited 17 February 2011. Available from http://english.hanban.org/node 10971.htm.

Hartig, Falk. 2012. Confucius institutes and the rise of China. Journal of Chinese Political Science 17(1):53-76.

Huggan, Graham. 2001. The Postcolonial Exotic: Marketing the Margins. New York: Routledge.

Ilnyckyj, Roma Areta. 2010. Learning as laowai: Race, social positioning, and Chinese language acquisition in China. Master's Thesis. Modern Language Education, University of British Columbia, Vancouver.

Kearney, M. 1995. The local and the global: The anthropology of globalization and transnationalism. Annual Review of Anthropology 24:547-565.

Keevak, Michael. 2011. Becoming Yellow: A Short History of Racial Thinking. Princeton, NJ: Princeton University Press.

Kunczik, Michael. 1997. Images of Nations and International Public Relations. Hillsdale, NJ: Lawrence Erlbaum Associates Publishers.

Kurlantzick, Joshua. 2007. Charm Offensive: How China's Soft Power is Transforming the World. New Haven, CT: Yale University Press.

Lancefield, Robert C. 2004. Hearing orientality in (white) America, 1900-1930. $\mathrm{PhD}$ Thesis, Wesleyan University.

Lau, Lisa. 2009. Re-Orientalism: The perpetration and development of Orientalism by Orientals. Modern Asian Studies 43(2):571-590.

Lee, Haiyan. 2006. Nannies for foreigners: The enchantment of Chinese womanhood in the age of millennial capitalism. Public Culture 18(3):507-529.

Li, Mingjiang. 2009. Soft power in Chinese discourse: Popularity and prospect. In M. Li, ed., Soft Power: China's Emerging Strategy in International Politics. Plymouth, UK: Lexington Books.

Mackey, Eva. 1999. The House of Difference: Cultural Politics and National Identity in Canada. New York: Routledge.

McClintock, Anne. 1995. Imperial Leather: Race, Gender, and Sexuality in the Colonial Contest. New York: Routledge.

Mitchell, Katharyne. 2004. Crossing the Neoliberal Line: Pacific Rim Migration and the Metropolis. Philadelphia: Temple University Press.

Morrow, Kathy. 2013. Fei Cheng Wu Rao (非诚勿扰): Staging global China through international format television. Presented at Imagining Globality: China's Global Projects in Culture. University of Alberta.

Nye, Joseph S. 1990. Bound to Lead: The Changing Nature of American Power. New York: Basic Books.

2008. Public diplomacy and soft power. The ANNALS of the American Academy of Political and Social Science 616:94-109. 
Nyíri, Pál. 2001. Expatriating is patriotic? The discourse on 'new migrants' in the People's Republic of China and identity construction among recent migrants from the PRC. Journal of Ethnic \& Migration Studies 27(4):635653.

Omi, Michael, and Howard Winant. 1993. On the theoretical status of the concept of race. In C. McCarthy, W. Crichlow, G. Dimitriadis and N. Dolby, eds., Race, Identity, and Representation in Education. New York: Routledge. 1994. Racial Formation in the United States: From the 1960s to the 1990s. New York: Routledge.

Paradise, James F. 2009. China and international harmony: The role of Confucius Institutes in bolstering Beijing's soft power. Asian Survey 49(4):647-669.

Paragg, Jillian. 2012. "Canadian-first": Mixed race self-identification and Canadian belonging. Unpublished paper: University of Alberta.

Robertson, Roland. 1992. Globality, global culture, and images of world order. In H. Haferhamp and N.J. Smelser, eds., Social Change and Modernity. Berkeley: University of California Press.

Rosenberg, Emily S. 1982. Spreading the American Dream: American Economic and Cultural Expansion, 1890-1945. New York: Hill and Wang.

Said, Edward. 1978. Orientalism. New York: Vintage Books.

Salgado, Minoli. 2011. The new cartographies of Re-Orientalism. The Journal of Commonwealth Literature 46(2):199-218.

Schein, Louisa. 1994. The consumption of color and the politics of white skin in post-Mao China. Social Text 41(Winter):141-164.

Siow, Maria Wey-Shen. 2011. China's Confucius Institutes: Crossing the river by feeling the stones. Asia Pacific Bulletin (January 6). http://www.eastwestcenter.org/publications/chinas-confucius-institutes-crossing-riverfeeling-stones.

Stanley, Phiona. 2013. A Critical Ethnography of 'Westerners' Teaching English in China: Shanghaied in Shanghai. New York: Routledge.

Stoler, Ann Laura. 1997. Racial histories and their regimes of truth. Political Power and Social Theory 11:183-206.

Teng, Emma Jinhua. 2006. Eurasian hybridity in Chinese utopian visions: From "one world" to "a society based on beauty" and beyond. Positions 14(1):131-163.

Thunø, Mette. 2001. Reaching out and incorporating Chinese overseas: The trans-territorial scope of the PRC by the end of the 20th century. The China Quarterly 168:910-929.

Tsing, Anna. 2008. The global situation. In J.X. Inda and R. Rosaldo, eds., The Anthropology of Globalization: A Reader. Malden, MA: Blackwell. 
Visweswaran, Kamala. 2010. Un/common Cultures: Racism and the Rearticulation of Cultural Difference. Durham, NC and London: Duke University Press.

Vukovich, Daniel. 2012. China and Orientalism: Western Knowledge Production and the PRC. New York: Routledge.

Wang, Q. Edward. 2003. Encountering the world: China and its other(s) in historical narratives, 1949-89. Journal of World History 14(3):327-358.

Yang Rui. 2010. Soft power and higher education: An examination of China's Confucius Institutes. Globalisation, Societies \& Education 8(2):235-245.

Yúdice, George. 2003. The Expediency of Culture: Uses of Culture in the Global Era. Durham, NC: Duke University Press.

Heather Schmidt is a doctoral candidate at the University of Alberta in the Department of Sociology, and a Research Associate at the China Institute on campus. Her main area of research interest involves cultural aspects of global and transnational processes, with a particular focus on China. Her current work examines the ways in which China's Confucius Institutes, as a global cultural project, imagine the world and China's place in it. 